\title{
A KÜLFÖLDI TANULÁSI MOTIVÁCIÓK ÉS A FELSŐOKTATÁSSAL VALÓ ELÉGEDETTSÉG ÖSSZEFÜGGÉSEI ${ }^{1}$
}

\author{
MUCSI ATTILA - MALOTA ERZSÉBET* - TÖRÖK ANNA \\ Budapesti Corvinus Egyetem
}

Kutatásunkban külföldi tanulmányi programban részt vevő hallgatók motivációs tényezőinek típusait és ezek elégedettséggel való kapcsolatát vizsgáltuk 20 külföldi hallgatóval készült mélyinterjú elemzésével. Eredményeink alapján hat motivációs csoport körvonalazódott: 1) társadalmi kényszer, 2) költséghatékony oktatás, 3) karrierépítés, 4) tanulmányok elmélyítése, 5) az adott ország megismerése és 6) élettapasztalat-szerzés. Azok a hallgatók, akik az ország megismerésére és élettapasztalat-szerzésre törekednek, sok esetben kihívásként tekintenek a külföldi tanulmányi program során tapasztalt nehézségekre, ami tovább növeli az elégedettségüket.

Kulcsszavak: külföldi hallgatók, külföldi hallgatók motivációi, push-pull tényezők, elégedettség a felsőoktatásban

In our research initial motivational factors that drive students to study abroad are categorized and the connection between these motivations and satisfaction with the higher educational institution is explored, with the help of 20 in-depth interviews. The analysis revealed six different groups of motivation: 1) social pressure, 2) cost-efficient education, 3) career building, 4) educational immersion, 5) country specific, and 6) life experience. Those students who thrive to collect life experience and learn about the host country generally handle study abroad difficulties as challenges to be solved, which further increases their satisfaction.

Keywords: international students, study abroad motivations, push-pull factors, satisfaction in higher education

\footnotetext{
* Levelező szerző: Malota Erzsébet, Budapesti Corvinus Egyetem, 1093 Budapest, Fővám tér 8. E-mail: erzsebet.malota@uni-corvinus.hu

1 A kutatást támogatta: EFOP-3.6.3.-VEKOP-16-2017-00007 „Tehetségből fiatal kutató” - A kutatói életpályát támogató tevékenységek a felsőoktatásban.
} 
— MUCSI ATTILA - MALOTA ERZSÉBET - TÖRÖK ANNA: A KÜLFÖLDI TANULÁSI MOTIVÁCIÓK... — -

\section{Bevezetés}

1

975-ben még csupán 800 ezer külföldi hallgató iratkozott be világszerte, míg 2015-ben a külföldi diákok száma meghaladta a 4,5 milliót (OECD 2017). A nemzetközi cserediákprogramok (például ERASMUS) szerepe kettős: egyik oldalról az egyetemi környezet nemzetköziesedését támogatja, másik oldalról pedig a részt vevő hallgatók kulturális kompetenciáját fejleszti (Leutwyler-Meierhans 2013).

A külföldi hallgatók motivációja és felsőoktatással kapcsolatos elégedettsége széles körben kutatott területek, azonban kevés tanulmány vizsgálja a kapcsolatot a külföldi diákok kezdeti személyes motivációi és a program végén mért elégedettsége között. A kutatás célja, hogy megértsük azt, hogy az egyes motivációs tényezők milyen mértékben és hogyan érvényesülnek, illetve ezek milyen hatással vannak a hallgatók elégedettségére.

\section{Szakirodalmi áttekintés}

\section{Tanulmányi motiváció elmélet}

A motiváció egy állandóan változó és összetett folyamat, amely belső pszichológiai tényezőkre épül. Ezen belső tényezők - azaz az egyéni szükségletek, vágyak és célok - határozzák meg, hogy mely ország mely intézményébe iratkoznak be a hallgatók (Maringe 2006). McMahon (1992) elsők között vizsgálta a külföldi hallgatók motivációit, amely eredményeképpen globális push (taszitó) tényezöket és országonként változó pull (vonzó) tényezőket állapított meg, azóta a kutatók többsége a tanulmányi motivációkat e két fö csoportba sorolja.

A hallgató először eldönti, hogy a hazai felsőoktatás helyett külföldön szeretne tanulni (push tényezők), ezt követően választja ki a fogadó országot - mely folyamat során a pull tényezők szerepe folyamatosan növekszik -, végül dönt a fogadóintézményről, mely döntés során már egyértelműen a pull tényezők dominálnak (Mazzarol-Soutar 2001; Gáti-Malota 2017).

A legfontosabb push tényezők közé sorolható a különböző társadalmak megértésének vágya (Mazzarol-Soutar 2001), a fogadó ország alacsony tandíja és megélhetési költsége (Hung-Chung-Ho 2000), a külföldi intézmények jó hírneve, észlelt minősége és felszereltsége (Maringe 2006), a külföldi diploma észlelt értéke, a hazai felsőoktatásba való bekerülés nehézsége, valamint a külföldön való letelepedés esélye. Leutwyler és Meierhans (2013) alapján a külföldi hallgatók motivációi személyes, szakmai és kulturális alapokon nyugszanak. A szerzőpáros által vizsgált 260 hallgató az alábbi indokok miatt döntött a külföldi cserefélév mellett:

- személyes látókör tágítása,

- idegen nyelvi készségek gyakorlása és fejlesztése,

- más kultúrából származó emberek iránti érdeklődés,

- tanulmányok mint befektetés,

- egy másik ország megismerése,

- szakmai előmenetel javítása,

- új dolgok megtapasztalása, 
- önellátóvá és önállóbbá válás iránti vágy,

- otthontól való távolság igénye,

- anyaintézménnyel való elégedetlenség,

- ismerős/rokon él a célországban.

A vizsgálat eredményei kapcsán kiemelendő, hogy az előbbiekben felsorolt 11 motivációs tényező közül csak a célországban élő ismerős az egyetlen pull összetevő.

A Magyarországon tanuló 1566 külföldi hallgató körében végzett felmérés alapján a hazai felsőoktatási intézményekben történő tanulmányokkal kapcsolatos döntés három leggyakrabban említett indoka a magas színvonalú oktatás (46\%), egy másik kultúra megismerésének vágya (46\%) és a megfizethető árak (43\%). Ez a három érv magasan kiemelkedik a felsoroltak közül, hiszen a többi választható indok esetében már csak $25 \%$ alatti említésszámok fordultak elő (Malota 2016).

A legfontosabb pull tényezők közé tartozik a célország ismerete és imázsa, a küldő és a fogadó ország közötti társadalmi és kulturális kapcsolat, a földrajzi közelség, az alumni hálózat fejlettsége és a hallgató korábbi kurzusteljesítései elfogadásának lehetősége (Mazzarol-Soutar 2012). Az intézményi pull tényezőket Sung és Yang (2008) három motivációs kategóriára osztotta: 1) az egyetem személyisége (barátságos, biztonságos, célszerü és szívélyes), 2) az egyetem presztízse (a társadalomban, médiában, ismerősök körében és egyetemi rangsorokban elfoglalt hely alapján) és 3) az egyetem hírneve (gondoskodik a hallgatókról, társadalmilag felelős és növekvő pályán van).

Mazzarol és munkatársai (Mazzarol-Kemp-Savery 1997) hat pull tényezőt azonosítottak: 1) az elérhető információ mennyisége és az elérés egyszerűsége, 2) a véleményformálók (szülők, barátok, toborzó) tanácsai, 3) a materiális (tandij, megélhetés, részmunkaidős lehetőség) és mentális (diszkrimináció, biztonság) költségek, 4) a fizikai (éghajlat) és érzelmi (életstílus) környezet, 5) a földrajzi közelség, valamint 6) a társadalmi kapcsolódás jelenleg vagy korábban ott élő vagy tanuló rokonokkal, barátokkal. Mindez rámutat arra is, hogy a fogadó országoknak és intézményeknek számos területen a célcsoport igényeihez kell alkalmazkodniuk (Kaszás-Péter-Németh 2015; Keller 2017).

$\mathrm{A} z$ intézmény kiválasztásában szerepet játszanak a szájreklám és a rokoni kapcsolatok is (Pimpa 2008). Leutwyler és Meierhans (2013) külföldi féléven részt vett svájci tanár szakos hallgatókon elvégzett kutatása alapján azok a hallgatók, akiknek legalább az egyik szülöje felsőoktatási képzésben vett részt, 20\%-kal nagyobb eséllyel kezdenek külföldi félévbe. Ebbe az organikus ajánlási folyamatba az intézmények bekapcsolódhatnak a potenciális hallgatók korai bevonása révén (Markos-Kujbus-Gáti 2012).

Kutatásunk során a push tényezőket a külföldi tanulmányok miértjeként értelmezzük, vagyis olyan kiinduló motivációkként, amelyek felébresztik a külföldön történő tanulás vágyát és az észlelt hiányt igyekeznek pótolni. A pull tényezőket másodlagos befolyásoló erőkként kezeljük, amelyek arra adják meg a választ, hogy hogyan és hol lehet a leghatékonyabban kielégíteni a külföldi tanulás iránti igényt.

\section{Külföldi hallgatók elégedettsége}

A külföldi hallgatók elégedettségére a fogadó ország és intézmény alapvető befolyással bír. Az elvárás-diszkonformitás paradigma alapján (Oliver 1980) az intézménnyel való elégedettség szintjét az határozza meg, hogy milyen irányú és mekkora a különbség 
a kiutazás előtt elvárt és a külföldi tanulmányok során észlelt minőségben. Amennyiben az észlelt minőség eléri vagy meghaladja az elvárásokat, a hallgató elégedett az intézménynyel, ellenkező esetben elégedetlen lesz, amelyet aktívan vagy passzívan is kifejezhet.

Wächter alapján (Joran 2011) a saját hazájukban tanuló hallgatók számára az akadémiai tényezők (oktatás színvonala és a professzorok tudása) határozzák meg az elégedettséget, míg a külföldi hallgatók esetében a személyes fejlődési lehetőség, a helyi légkör (város, ország) és a karrierépítés is megjelennek befolyásoló tényezőként. A részképzéses külföldi hallgatók számára az ún. soft skilleket érintő személyes fejlődés és helyi légkör tipikusan fontosabbak az oktatás színvonalánál, a teljes képzésben részt vevő külföldi hallgatók számára az oktatás minősége és a karrierépítés lehetősége a meghatározó tényezők (ACA 2006). Wächter azt is kiemeli, hogy az eltérő motivációk nyomán eltérő elégedettségi tényezők jelenhetnek meg az európai és Európán kívüli hallgatók körében. Tovább árnyalja a képet az a tendencia, hogy a kevésbé népszerü célországokba (például Portugália, Lengyelország) alacsonyabb elvárással érkező hallgatók pozitívabban nyilatkoznak a fogadóintézményről, mint a presztízscélországokba (például Egyesült Királyság) magas elvárással érkező hallgatók (Joran 2011).

Joran (2011) Erasmus-hallgatókat vizsgáló kutatása alapján a cserediákok elégedettségének fő forrásai a személyes és szakmai fejlődés (29\%), a város és kultúrája (27\%), az akadémiai tényezők (21\%), a közösségi élet (14\%), valamint a költségek és az egyetemi szolgáltatások (7\%).

Houng és munkatársai vietnami hallgatók ausztráliai felsőoktatási intézményi tapasztalatai alapján az alábbi három elégedetlenséget okozó tényezőt állapították meg: 1) a hallgatók a külföldi oktatóktól nem a saját kultúrájukban tapasztalt oktatási stílust kapják, 2) a tantárgy nyelvét nem megfelelő szinten ismerik, illetve 3) az egyetem bizonyos szolgáltatásairól nincs tudomásuk és ezért nem tudják azokat előnyükre fordítani (Houng et al. 2017).

\section{A kutatás módszertana}

A kutatás során 20 darab félig strukturált mélyinterjút készítettünk európai tanulmányokat folytató külföldi - 10 európai és 10 Európán kívüli - hallgatóval. Az interjúkat tartalomelemzéssel dolgoztuk fel.

$\mathrm{A} z$ interjúalanyok kiválasztásakor kényelmi mintavételt alkalmaztunk, a diverzitás növelése céljából az európai és nem európai interjúalanyok arányát 50-50\%-ban határoztuk meg. Az interjúk a 2018-as őszi félévben készültek olyan külföldi hallgatókkal, akik legalább három hónapos külföldi tanulmányi programban vettek részt az elmúlt három évben. Az interjúk 60-90 perc hosszúságúak voltak. A kutatás validitásának növelése érdekében az interjúkat hangfelvételként is rögzítettük, emellett minden interjút követően féloldalas kutatói önreflexió is készült.

$\mathrm{A} z$ interjúleiratokat kettős szakértői kódolással végeztük el három fázisban (Lehota 2001). A kvalitatív tartalomelemzés jellegében induktív (feltáró), tehát előre meg nem határozott kategóriák szerint történt, de szükség esetén a szakirodalom alapján deduktív (következtető) elemek is megjelentek (Patton 2002; Berg 2001). A fenti megközelítés lehetővé teszi a külföldi hallgatók motivációs tényezőinek újszerü modellezését és csoportosítását, esetenként a már létező szakirodalomra támaszkodva, illetve kibővítve azt. 
A tartalomelemzés kvalitatív mivoltából adódóan az interjúalanyok gondolatait az adott kontextusban szisztematikusan dolgoztuk fel egy előre megállapított elemzési rendszer alapján (Mayring 2000). A kutatásnak nem képezi részét az interjúleiratok kvantitatív elemzése, amely a szavak és kifejezések előfordulási gyakoriságát méri.

\section{Kezdeti motivációk csoportosítása}

A motivációs csoport olyan külföldi tanulmányok megkezdéséhez kapcsolódó motivációk összessége, amelyek eltérő mértékben és irányban befolyásolhatják a külföldi tanulmányi félév végén tapasztalt elégedettséget. A hallgatók kezdeti motivációit az interjúk alapján hat csoportba kategorizáltuk, melyet az 1. táblázatban foglaltunk össze. Minden hallgatónak volt egy domináns motivációs csoportja, amely egy vagy több egyéb (társ-) motivációs csoporttal egészült ki.

1. táblázat: Motivációk és elégedettség

\begin{tabular}{|l|l|l|l|}
\hline $\begin{array}{l}\text { Motivációs } \\
\text { kategória }\end{array}$ & \multicolumn{1}{|c|}{ Motivációs kategória jellemzése } & \multicolumn{1}{|c|}{$\begin{array}{c}\text { Tipikus társ } \\
\text { motivációs csoport }\end{array}$} & \multicolumn{1}{|c|}{$\begin{array}{c}\text { Elégedettség } \\
\text { szintje }\end{array}$} \\
\hline $\begin{array}{l}\text { Társadalmi } \\
\text { kényszer }\end{array}$ & $\begin{array}{l}\text { Hallgatótársakhoz, munkatársakhoz, } \\
\text { intézményi vagy munkahelyi elvárásokhoz } \\
\text { igazodás, személyes probléma elöl menekülés }\end{array}$ & $\begin{array}{l}\text { Költséghatékony } \\
\text { oktatás; Karrier- } \\
\text { építés }\end{array}$ & $\begin{array}{l}\text { Alacsony, társ } \\
\text { motivációval is } \\
\text { alacsony }\end{array}$ \\
\hline $\begin{array}{l}\text { Költséghatékony } \\
\text { oktatás }\end{array}$ & $\begin{array}{l}\text { Alacsony tandíj, megélhetési költség, kedve- } \\
\text { ző ösztöndíj-lehetőség }\end{array}$ & $\begin{array}{l}\text { Élettapasztalat- } \\
\text { szerzés; Ország } \\
\text { megismerése }\end{array}$ & $\begin{array}{l}\text { Alacsony, társ mo- } \\
\text { tivációval közepes }\end{array}$ \\
\hline $\begin{array}{l}\text { Karrierépítés } \\
\text { Oözéletrajz gazdagítása hazai vagy nemzet- } \\
\text { felkészülés }\end{array}$ & $\begin{array}{l}\text { Ország megisme- } \\
\text { rése }\end{array}$ & $\begin{array}{l}\text { Alacsony, társ mo- } \\
\text { tivációval közepes }\end{array}$ \\
\hline $\begin{array}{l}\text { Tanulmányok } \\
\text { elmélyítése }\end{array}$ & $\begin{array}{l}\text { Minőségi oktatás, kedvező tanulmányi relokációra való } \\
\text { program feltételek, tantárgykínálat }\end{array}$ & Karrierépítés & $\begin{array}{l}\text { Közepes, társ moti- } \\
\text { vációval közepes }\end{array}$ \\
\hline $\begin{array}{l}\text { Ország megis- } \\
\text { merése }\end{array}$ & $\begin{array}{l}\text { Országspecifikus kulturális, nyelvi, utazási, } \\
\text { történelmi, politikai érdeklődés }\end{array}$ & $\begin{array}{l}\text { Élettapasztalat- } \\
\text { szerzés }\end{array}$ & $\begin{array}{l}\text { Magas, társ motivá- } \\
\text { cióval magas }\end{array}$ \\
\hline $\begin{array}{l}\text { Élettapasztalat- } \\
\text { szerzés }\end{array}$ & $\begin{array}{l}\text { Utazás, kihívás, barátok szerzése, idegen } \\
\text { nyelv használata, önállósodás, szórakozás }\end{array}$ & $\begin{array}{l}\text { Ország megisme- } \\
\text { rése }\end{array}$ & $\begin{array}{l}\text { Magas, társ motivá- } \\
\text { cióval magas }\end{array}$ \\
\hline
\end{tabular}

A Joran (2011) kutatása során megállapított öt csoporthoz képest új, önálló kategóriaként jelenik meg a társadalmi norma és a szakmai előmenetel, azonban a személyes fejlődés és a közösségi élet összeolvad. A Leutwyler és Meierhans (2013) által gyűjtött push motivációk, illetve Mazzarol, Kemp és Savery (1997) pull tényezői szintén bekategorizálhatóak az új modellben attól függően, hogy az elégedettséget milyen mértékben és irányban befolyásolják. A továbbiakban példákkal és idézetekkel részletezve mutatjuk be a motivációs csoportok közötti főbb hasonlóságokat és különbségeket.

\section{Motivációs csoportok és elégedettség}

Az azonosított motivációs kategóriák olyan külföldi tanulmányi célokat jelölnek, amelyek mentén a hallgatók értékelték a külföldi tanulmányi útjuk sikerét, illetve a fogadó országgal és intézménnyel való elégedettségüket. 
— MUCSI ATTILA - MALOTA ERZSÉBET - TÖRÖK ANNA: A KÜLFÖLDI TANULÁSI MOTIVÁCIÓK... — -

\section{Társadalmi kényszer}

A társadalmi kényszeren alapuló motivációk esetén a hallgató nem a személyes érdekei mentén döntött a külföldi tanulmányi félév megkezdéséről, hanem egy külső nyomásnak igyekezett eleget tenni. A vizsgált húsz hallgató közül összesen öten, számos formában említették ezt fö motivációként (egyéb másodlagos motivációk mellett)ः „A munkatársaim nagy részének külföldi diplomája van, ezért ideje volt nekem is elgondolkozni rajta" vagy „A külföldi félév kötelező a szakirányomon, tehát nem volt más választásom”. Ennél árnyaltabb formában, kevésbé konkrétan is megjelentek ezek a külső motivációs tényezők, például: "Mindenki tanul valamennyit külföldön, ez a normális".

Azok a külföldi hallgatók, akiknél a társadalmi kényszer volt a fő motiváló erő, kevésbé voltak elégedettek. Ebbe a csoportba jellemzően nem európai állampolgárok (indonéz, indiai, kínai) kerültek, akik Európában tanultak. A társadalmi kényszer gyakran párosult a költséghatékonyság és a karrierépítés kategóriákkal, amelyek együttesen jellemzően csökkentették az elégedettséget. A belső motiváció hiányában ezek a hallgatók kevésbé alkalmazkodtak (nem tartották érdeküknek az alkalmazkodást) a fogadó országhoz, ennek megfelelően kevesebb sikerélményben volt részük, ami az elégedettség hiányához vezetett.

\section{Költséghatékony oktatás}

Két hallgató kizárólag ösztöndíjprogramok keretében tudta megoldani a külföldi utazást: „Hallottam egy európai ösztöndij lehetöségröl és ezért jelentkeztem. Az ösztöndij volt a legfontosabb, anélkül nem mentem volna külföldre."

A költséghatékony oktatás mellett több hallgatónál is megjelent az élettapasztalatszerzés és az ország megismerésének vágya, amelyek ugyan csökkentették az árérzékenység okozta stresszt külföldön, azonban a pénzügyi korlátok miatt összességében alacsony szintű elégedettséget eredményeztek.

\section{Karrierépités}

A vizsgált húsz hallgató negyede említette a karrierépítést mint fó motivációs tényezőt: "Jobbak a munkalehetöségek külföldön, de elöször meg kell tapasztalnom a kinti életet."

A kizárólag a karrierépítést megcélzó hallgatók általában nem voltak elégedettek, mert a külföldi tanulmányok során nem volt annyi kapcsolatépítési lehetőségük a helyiekkel, mint ahogy azt korábban tervezték. Azok a külföldi hallgatók, akik egyúttal az országot is meg akarták ismerni (utazás, helyi nyelv) általában elégedettek voltak a tanulmányi programmal.

\section{Tanulmányok elmélyitése}

$\mathrm{A} z$ akadémiai eredmények mindössze három hallgató számára bírtak kiemelkedő fontossággal, azon belül az oktatás minősége, a széles tárgykínálat, az intézmény hírneve és presztízse kerültek előtérbe, amely megegyezik Sung és Yang (2008) pull tényezőivel: "Csak nagyon jól ismert egyetemre akartam menni, aminek jó híre van a világban." 
A tanulmányok elmélyítése mellett főként a karrierépítés dominált: ezekhez a motivációs csoportokhoz köthető hallgatók jellemzően kritikusak voltak a fogadó intézménnyel kapcsolatban, de összességében elégedettek voltak a tanulmányi programmal.

\section{Az ország megismerése}

Összesen tizenkét hallgatónál megjelent legalább másodlagos motivációként az ország megismerése valamilyen formában. Leggyakrabban a helyi nyelv elsajátítása, a helyi emberek életének megismerése, utazás az országban vagy egy adott város meglátogatása volt a cél.

Gyakran személyes kötődés alapján történt a fogadó ország kiválasztása (szülők ott éltek, korábbi nyaralás, barátok voltak ott stb.). Mivel ezek a hallgatók általában megbízható forrásból megfelelő mennyiségü információval rendelkeztek a fogadó országról, ezért nagyon elégedettek voltak, még akkor is, ha negatív tapasztalatokat szereztek. Ez a fajta kulturális nyitottság elnézőbb a fogadóintézményben tapasztalt problémákkal is, hiszen a hallgató részben élettapasztalatot gyüjt: „Az adminisztráció elavult, lassú és kaotikus. Néhány tárgy szervezetlen volt, de voltak nagyon érdekes tantárgyaim is, amiket Norvégiában sose tudtam volna felvenni, szóval elégedett vagyok."

\section{Élettapasztalat-szerzés}

Kilenc külföldi hallgató esetében a személyes tapasztalatszerzés is helyet kapott: „Ujj emberekkel akartam találkozni, valami mást akartam csinálni, kimozdulok végre a komfortzónámból." E kategória gyakran párosult egy adott ország megismerésének az igényével.

Mivel a hallgatók célja a tapasztalatszerzés volt, ezért sok esetben a negatív tapasztalat szerzése is egyfajta elégedettséget eredményezett: „Az év eleji nehézségeket félretéve elégedett vagyok, jók voltak az órák, a tanárok is rendben voltak. Kell egy kis idö, hogy megszokja az ember, mert Ausztráliában máshogy mennek a dolgok (kevesebb a papírmunka), de javasolnám az ismeröseimnek, bogy próbálják ki."

$\mathrm{A} z$ élettapasztalattal kapcsolatos motivációs csoport kimagasló elégedettséghez vezetett, fóként azért, mert a hallgatók önszántukból feszegették a saját határaikat és kifejezetten keresték az extrém különbségeket, így a negatív tapasztalatok hozzáadott értéket képviseltek, amiből tanulni tudtak. Ezek a külföldi hallgatók a fogadó intézménnyel és országgal egyaránt nagyon elégedettek voltak.

\section{Következtetések, javaslatok}

Kutatásunk során azt vizsgáltuk, hogy a külföldi program megkezdése elött kialakult motivációk beteljesülésének szintje milyen módon befolyásolja a külföldi hallgatók elégedettségét a tanulmányi program végén. Elemzésünkben hat motivációs csoportot azonosítottunk: 1) társadalmi kényszer, 2) költséghatékony oktatás, 3) karrierépítés, 4) tanulmányok elmélyítése, 5) az adott ország megismerése és 6) élettapasztalatszerzés. Eredményeink szerint a motivációs kategóriák egymással párhuzamosan létezhetnek, azonban legalább egy tényező dominál. Amennyiben a hallgató kezdeti motivációi között domináns tényezőként szerepel az élettapasztalat-szerzés vagy az ország megismerése, akkor a hallgató nagyobb valószínűséggel lesz elégedett, mintha a 
másik négy kategória egyike dominálna. Emellett az ezekre törekvő külföldi hallgatók rugalmasabban kezelik a külföldi tanulmányi program során tapasztalt nehézségeket, sok esetben kihívásként tekintenek rájuk, amely tovább növeli az elégedettségüket (sikeres megoldás esetén).

A tradicionális push és pull motivációs tényezökre alapozva a fogadó országok és intézmények össze tudják állítani a jövőbeli diákok számára legvonzóbb tanulmányi programot. A felsőoktatási intézmények a kutatásunk során kialakított kategorizálás alapján a külföldi tanulmányi félév megkezdésekor fel tudják mérni, hogy mely hallgatók igényelnek több figyelmet és milyen területen. Például a társadalmi kényszerrel kapcsolatos motivációs csoport esetén a legvalószínütlenebb a programmal való elégedettség, tehát ebben az esetben az intézmény támogathatná a külföldi hallgatót a tanulmányi program során abban, hogy találjon egy hozzá közel álló motivációs csoportot. A költséghatékony oktatással összefüggő motivációs csoport nagyon árérzékeny, ezért fennáll a veszélye annak, hogy a hallgató nem mozdul ki otthonról (vagy a könyvtárból). Ezeknek a diákoknak érdemes felhívni a figyelmét az ingyenes egyetemi programokra és az olcsó (csoportos) utazási lehetőségekre. A karrierépítésre és tanulmányokra fókuszáló hallgatók esetében a kapcsolatépítés és a professzorok figyelme az elsődleges, tehát a nemzetközi iroda a megfelelő óraadókkal tudna egyeztetni arról, hogy mely hallgatók milyen motivációkkal érkeztek. Az élettapasztalat szerzésére és az ország megismerésére törekvő külföldi hallgatók lesznek várhatóan a legelégedettebbek, őket érdemes bevonni a nemzetközi koordinátorok és a diákszervezetek munkájának segítésébe.

További kutatási irány lehet annak vizsgálata, hogy a hallgatói elégedettség milyen hatást gyakorol a felsőoktatási intézmények müködésére, eredményességére, illetve hogy a klasszikus elégedettség-lojalitás kapcsolat hogyan értelmezhető az egyetemek kontextusában (Gyulavári 2013).

\section{IRODALOM}

AcA (2006) Perceptions of European Higher Education in Third Countries. Brussels, Belgium.

Berg, B. L. (2001) Qualitative Research Methods for the Social Sciences. Boston, Allyn and Bacon.

Gáti M. \& Malota E. (2017) The Relationship between International Students' Satisfaction with General and Educational Facilities and Their Repeated Choice Concerning the Higher Educational Destination. In: Ch. Gómez, L. Martínez \& C. Torres (eds) EDULEARN17 Proceedings: 9th International Conference on Education and New Learning Technologies. Barcelona: International Academy of Technology, Education and Development (IATED). pp. 3753-3763.

Gyulavári T. (2013) Lojalitási programok menedzselése. Vezetéstudomány, Vol. 43. No. 5. pp. $16-26$.

Hung, F. S., Chung, P. \& Ho, C. (2000) To Work or to Continue to Higher Education? The Choice of Senior Secondary Students in Shenzhen, China. Higher Education, Vol. 39. No. 4. pp. 455-467.

Huong, L., Fung, K. K., Rodney, A. \& Ambika, Z. (2017) Voices of Dissent: Unpacking Vietnamese International Student Experience. International Journal of Educational Management, Vol. 31. No. 3. pp. 280-292. 
Joran van Art (2011) Key Influencers of International Student Satisfaction in Europe. Eindhoven, Study Portals.

Kaszás N., Péter E. \& Németh K. (2015) A tudásátadás különböző formáinak megjelenítése a határon átnyúló pályázati projektek esetében. In: Ferencz Á. (ed.) II. Gazdálkodás és Menedzsment Tudományos Konferencia: „A vidék él és élni akar." Kecskemét, Kecskeméti Főiskola Kertészeti Főiskolai Kar. pp. 135-140.

Keller K. (2017) A turizmusmarketing környezete. In: Lőrincz K. \& Sulyok J. (ed.) Turizmusmarketing. Budapest, Akadémiai Kiadó, pp. 39-61.

Lенота J. (2001) Marketingkutatás az agrárgazdaságban. Budapest, Mezőgazda Lap- és Könyvkiadó Kft.

Leutwyler, B. \& Meierhans, C. (2013) Exchange Students in Teacher Education. Empirical Evidence on Characteristics and Motive. Educational Research, Vol. 4. No. 1. pp. 1-11.

Malota E. (2016) Hallgatói véleményfelmérés 2016: Magyarország és a magyar felsöoktatás a külföldi ballgatók szerint. Budapest, Tempus Közalapítvány.

Maringe, F. (2006) University and Course Choice: Implications for Positioning, Recruitment and Marketing. International Journal of Educational Management, Vol. 20. No. 6. pp. 466-479.

Markos-Kujbus É. \& Gáti M. (2012) Social Media’s New Role in Marketing Communication and Its Opportunities in Online Strategy Building. ECREA 2012 - 4th European Communication Conference. 24-27 October, 2012., Istanbul, Turkey.

Mayring, P. (2000) Qualitative Content Analysis. Forum: Qualitative Social Research, Vol. 1. No. 2.

Mazzarol, T., Kemp, S. \& Savery, L. (1997) International Students Who Choose Not to Study in Australia: An Examination of Taiwan and Indonesia. Canberra, Australian International Education Foundation.

Mazzarol, T. \& Soutar, N. G. (2001) The Global Market for Higher Education: Sustainable Competitive Strategies for the New Millennium. Cheltenham, Edward Elgar.

Mazzarol, T. \& Soutar, N. G. (2012) Revisiting the Global Market for Higher Education. Asia Pacific Journal of Marketing and Logistics, Vol. 24. No. 5. pp. 717-737.

McManon, M. (1992) Higher Education in a World Market: An Historical Look at the Global Context of International Study. Higher Education, Vol. 24. No. 4. pp. 465-82.

OECD (2017) OECD: Nemzetközi Diákok száma. http://monitor.icef.com/2017/09/oecdcharts-slowing-international-mobility-growth/ [Letöltve: 2019. 05. 05.]

Oliver, R. L. (1980) A Cognitive Model of the Antecedents and Consequences of Satisfaction Decisions. Journal of Marketing Research, Vol. 17. No. 4. pp. 460-469.

Patton, M. Q. (2002) Qualitative Research and Evaluation Methods. Thousand Oaks (CA), Sage.

Pimpa, N. (2008) Marketing International Higher Education: A Case of Thai Students in Australia. International Journal of Management in Education, Vol. 2. No. 2. pp. 154-71.

Sung, M. \& YAnG, S. U. (2008) Toward the Model of University Image: The Influence of Brand Personality, External Prestige, and Reputation. Journal of Public Relations Research, Vol. 20. No. 4. pp. 357-376.

A cikk a Creative Commons Attribution 4.0 International License (https://creativecommons.org/licenses/ by/4.0/) feltételei szerint publikált Open Access közlemény, melynek szellemében a cikk bármilyen médiumban szabadon felhasználható, megosztható és újraközölhető, feltéve, hogy az eredeti szerző és a közlés helye, illetve a CC License linkje és az esetlegesen végrehajtott módosítások feltüntetésre kerülnek. (SID_1) 